\title{
Nese og lunger - to sider av samme sak
}

\begin{abstract}
Sammendrag
Bakgrunn. Sykdommer i øvre og nedre luftveier forekommer ofte samtidig, og det er sterke holdepunkter for at de har noe med hverandre å gjøre. Kunnskap om dette er viktig for å kunne behandle luftveissykdommer på best mulig måte, og denne artikkelen gir en oppdatert oversikt over feltet.
\end{abstract}

Materiale og metode. Artikkelen baserer seg på lang klinisk erfaring med luftveissykdommer, egen forskning på området og litteraturstudier.

Resultater. Det er godt dokumentert at det er en overhyppighet av neseplager hos pasienter med astma. På samme måte vet vi at pasienter med nesebihule-sykdom som for eksempel høysnue, nesepolypper og bihulebetennelser hyppigere har astma enn personer uten slik sykdom. Behandling av sykdom i ett avsnitt av luftveiene har ofte positive konsekvenser for luftveiene i sin helhet.

Fortolkning. Sykdommer i øvre og nedre luftveier bør i større grad enn i dag betraktes som en og samme tilstand. Pasienter med sykdom i ett avsnitt av luftveiene bør vurderes med tanke på om andre deler også er involvert. Behandlingsmessig bør luftveiene betraktes som en enhet.

\section{Sverre K. Steinsvåg}

sverre.steinsvag@sshf.no

$\emptyset$ re-nese-hals-avdelingen

Sørlandet sykehus

4604 Kristiansand

og

Øre-nese-hals-avdelingen

Haukeland universitetssykehus

Nesen og lungene er tradisjonelt blitt behandlet som ulike og uavhengige organer. I dag vet vi at disse enhetene har mange anatomiske fellestrekk og er tett knyttet til hverandre både fysiologisk, patofysiologisk, epidemiologisk og behandlingsmessig. Det er viktig at denne kunnskapen implementeres $\mathrm{i}$ daglig medisinsk praksis for å sikre at et stadig økende antall pasienter med kroniske luftveissykdommer får best mulig utredning og behandling. Denne artikkelen er skrevet for å øke bevisstgjøringen omkring disse forholdene.

\section{Materiale og metode}

Artikkelen er forfattet på bakgrunn av lang klinisk erfaring med luftveissykdommer, egen pågående forskning og et ikke-systematisk søk i PubMed.

\section{Anatomisk-fysiologisk perspektiv}

Slimhinnen som kler nese og den som kler bronkier er nærmest identisk, først og fremst karakterisert av det ciliebærende overgangsepitelet. Integrert i denne slimhinnen finner vi to forsvarssystemer. Det ene er immunologisk basert, med immunregulering, immuneliminering og immuneksklusjon som sentrale elementer. Det andre består av flimmerhår og luftveissekret. Det er imidlertid to patofysiologisk viktige anatomiske forskjeller på vevet som omgir øvre og nedre luftveier. Bronkier er omgitt av glatt muskulatur som spiller en rolle $\mathrm{i}$ forbindelse med obstruktive lungesykdommer. I nesen er det i første rekke venøse sinusoider som regulerer grad av tetthet.

Normalt passerer inspirasjonsluften nesen på vei ned i lungene. I løpet av denne passasjen vil luften varmes opp og tilføres fuktighet og nitrogenmonoksid. Den vil også renses for partikler over ca. $10 \mu \mathrm{m}$ i diameter og for vannløslige gasser. Dette er prosesser som gjør at luften som har passert nesen på vei ned i lungene, har en optimal temperatur, fuktighet og sammensetning (1). Et annet viktig forhold er at ca. $50 \%$ av den totale luftveismotstanden sitter i de ytterste centimeterne av nesen. Dette betyr at tilstander lengst framme i nesen og behandlingen av disse er av stor betydning for luftveiene som helhet.

\section{Epidemiologisk perspektiv}

Sykdommer i øvre og nedre luftveier forekommer ofte samtidig. 75-95\% av voksne pasienter med allergisk og ikke-allergisk astma har rhinitt (2). Samtidig forekomst av allergisk rhinitt er assosiert med alvorligere astmasymptomer, større problemer med å kontrollere lungesymptomene og mer redusert livskvalitet.

Man regner med at så mange som $75 \%$ av pasientene med kronisk obstruktiv lungesykdom har samtidige symptomer fra nesen (3).

Forekomst og grad av astma ser ut til å øke med varighet og alvorlighet av neseplagene (4). Barn og voksne med astma og rhinitt har en signifikant hyppigere kontakt med allmennlege for sin astma enn personer som bare har astma. De har også flere sykehusinnleggelser og bruker mer medisiner (4). Det ser også ut til å være en tidsmessig relasjon mellom symptomer fra nese og lunger; neseplagene kommer ofte før astmasymptomene.

$40 \%$ av pasienter med allergisk sesongog helårsrhinitt har også astma (4). Pasienter med allergisk rhinitt uten manifest astma har ofte økt uspesifikk bronkial hyperreaktivitet (5).

Det er en overhyppighet av astma og kronisk obstruktiv lungesykdom hos pasienter med akutte og kroniske bihulebetennelser (3). Pasienter med alvorlig astma hadde høyere symptomskår på bihulesykdom, mer uttalte bihuleforandringer ved CT og mer uttalte morfologiske forandringer i bihuleslimhinnene enn pasienter som hadde mindre alvorlig astma $(6,7)$. Relasjonen mellom

\section{Hovedbudskap}

- Begrepet «en luftvei - en sykdom» blir stadig sterkere vitenskapelig underbygget

- Astma, kronisk obstruktive lungesykdommer, rhinitt og sinusitt bør betraktes som ulike manifestasjoner av en og samme sykdom

- Dette bør få konsekvenser for utredning og behandling av både neseog lungesykdommer 
astma og bihulesykdom støttes av at førstnevnte har en negativ prediktiv verdi når det gjelder resultat av kirurgisk behandling av bihulebetennelser (8).

Nesepolypper er også forbundet med en overhyppighet av astma og obstruktive lungesykdommer (9). I den sammenheng er pasienter med acetylsalisylsyreintoleranse særlig aktuelle idet disse ofte har både nesepolypper og astma, den såkalte Samters triade (10).

Det ser ut til å være en sammenheng mellom infeksiøse rhinitter og astma (11). Infeksjoner med respiratorisk syncytialvirus (RSV) i øvre luftveier disponerer for astma hos de minste barna, mens rhinovirusinfeksjoner har tilsvarende rolle hos eldre barn, unge og voksne. Det ser også ut til at barn med astma har trangere passasjeforhold gjennom nesesvelget enn barn uten astma (12).

\section{Patofysiologisk perspektiv}

Det er fire mulige tilgrunnliggende mekanismer bak sammenhengen mellom nese og lunger i et patofysiologisk perspektiv (fig 1).

\section{Immunologisk sammenheng}

mellom sykdom i øvre og nedre luftveier

Nasal allergen provokasjon utløser bronkial inflammasjon på samme måte som bronkial provokasjon utløser nasal inflammasjon (4). Rhinitt og astma kjennetegnes av mange av de samme inflammatoriske prosessene (13). Dette indikerer en immunologisk sammenheng mellom sykdom i de to luftveisavsnittene. Detaljene i denne sammenhengen er fortsatt under utforskning.

Det er ofte neseslimhinnen som først kommer i kontakt med allergener, mikrober og irritanter. Mens de morfologiske konsekvensene i nesen som regel er begrenset kan de tilsvarende forandringer i lungene være omfattende. Dermed kan det se ut som nesen har mekanismer som beskytter mot epitelskade, stimulerer epitelial regenerasjon og begrenser remodellering i større grad enn lungene (14).

\section{Transluminal spredning}

Hos ellers friske mennesker vil både hosterefleksen og det mukociliære apparatet motvirke en slik spredningsmåte (15). Hos for eksempel intuberte pasienter, med nedsatt hosterefleks og nedsatt mukociliær aktivitet, kan imidlertid dette skje. Det er en av grunnene til at langtidsintubasjon bør unngås.

\section{Nevrogen overføring}

Inflammatoriske tilstander og kjemiske, termiske og biologiske irritanter genererer impulser i nerver i neseslimhinnen. Slike impulser kan utløse kontraksjoner i glatt muskulatur som omgir bronkialtreet. Ved kroniske inflammatoriske luftveissykdommer ser man nevrogen hyperreaktivitet. Denne bidrar sannsynligvis til den kroniske sykdomsprosessen i både øvre og nedre luftveier (16).
Lungesykdom som negativ konsekvens av munnpusting

Nesepusting tilfører lungene temperert, fuktet og renset luft. Dette er viktig for en normal lungefunksjon. Astmatikere har større tendens til munnpusting enn lungefriske, og man spekulerer på om dette kan spille en rolle i utviklingen av lungesykdommen $(17,18)$.

Betydningen av nesepusting for å beskytte lungene understrekes gjennom forskning på anstrengelsesutløst astma. Tilstanden kan være en konsekvens av at man under fysisk anstrengelse i større grad enn ellers puster gjennom munnen.

\section{Behandlingsmessig perspektiv}

Medikamentell og kirurgisk behandling av inflammasjon, infeksjon og tetthet i nesen kan ha positive effekter på samtidig forekommende sykdommer i lungene (19). Å unnlate å behandle rhinitt hos pasienter med astma kan forhindre astmakontroll og forverre prognosen.

Nasale steroider er sentrale i behandlingen av øvre luftveisallergi samt akutte og kroniske sinusitter (20). Det er sterke holdepunkter for at de også har gunstige effekter på astma (21-23).

Antihistaminer kan redusere symptomer på allergisk rhinitt og samtidig forekommende bronkial hyperreaktivitet og astma (24). Dette skyldes dels en blokkering av perifere histaminreseptorer og dels en antiinflammatorisk effekt.

Leukotrienantagonister, alene eller sammen med antihistaminer, gitt til pasienter med allergisk rhinitt og astma, har også gunstig effekt på begge tilstandene (25).

Spesifikk immunterapi, allergivaksinasjon eller hyposensibilisering, kan både redusere symptomer og medisinbruk i forbindelse med allergisk rhinokonjunktivitt og allergisk astma samt forebygge utviklingen av sistnevnte og bronkial hyperreaktivitet (26). På samme måte kan anti-IgE redusere symptomskår for astma og rhinitt og forbedre nese- og lungerelatert livskvalitet (27).

Medikamentell og kirurgisk behandling av nese og bihulebetennelser hos pasienter som samtidig har astma kan bedre astmasymptomene, gi bedre luftveisbetinget livskvalitet og redusere bruk av astmamedisiner (28).

Adenotonsillektomi kan redusere lungesymptomene hos dem som samtidig har astma. Inngrepet reduserer også behovet for medikamentell astmabehandling (29). En undersøkelse av om ren adenotomi har samme positive effekt er i gangsatt ved Sørlandet sykehus, men foreløpig er bare få pasienter inkludert.

Kunnskapen om hvordan sykdom i øvre og nedre luftveier henger sammen, bør få konsekvenser for hvordan pasienter med slike tilstander utredes og behandles både $\mathrm{i}$ primærhelsetjenesten og spesialisthelsetjenesten. Man bør spesielt tilstrebe et tettere og mer formalisert samarbeid mellom ulike

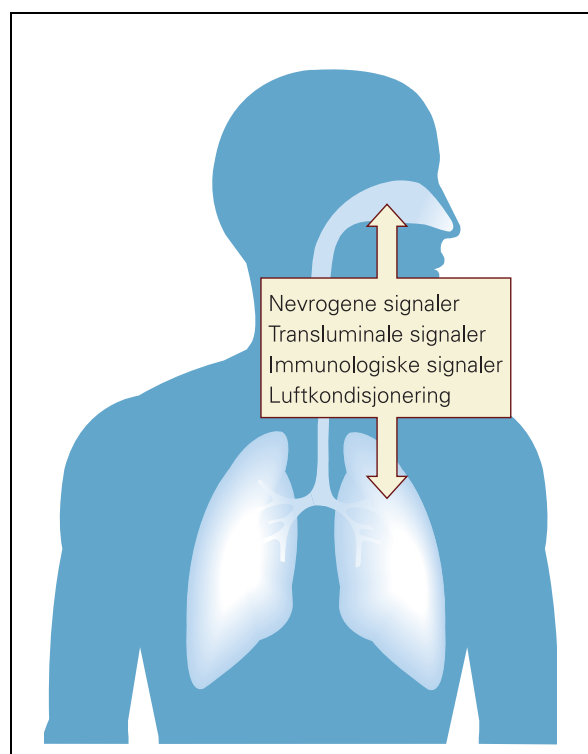

Figur 1 Patofysiologisk grunnlag for at nese og lunger fungerer som en enhet

typer spesialister som arbeider med luftveissykdommer både hos barn og voksne. Rhinitt, sinusitt, astma og kronisk obstruktive lungesykdommer er i mange tilfeller en konsekvens av samme inflammatoriske prosess. Pasienter med slike sykdommer bør derfor alltid vurderes med tanke på samtidig sykdom $i$ andre deler av luftveiene. Det er viktig å forebygge og behandle felles årsaksforhold, som allergi og røyking. Det er også viktig med økt oppmerksomhet på å redusere inflammasjon og tiltak for å bedre passasjeforholdene i øvre luftveier til fordel også for nedre luftveier.

Oppgitte interessekonflikter: Ingen

\section{Litteratur}

1. Togias A, Windom J. The impact of nasal function and dysfunction on the lower airways. I: Corren J, Togias A, Bousquet J, red. Lung biology in health and disease. Bd. 181. New York: Marcel Dekker, $2004: 53-86$

2. Bousquet J, Khatalev N, Cruz A et al. Allergic rhinitis and its impact on asthma (ARIA) 2008 update. Allergy 2008; 63 (suppl 86): 75-84.

3. Kim J. Rubin B. Nasal and sinus inflammation in chronic obstructive pulmonary disease. COPD 2007; 4: 163-6.

4. Cruz A, Popov T, Pawankar R et al. Common characteristics of upper and lower airways in rhinitis and asthma: ARIA update, in collaboration with GA(2)LEN. Allergy 2007; 62 (suppl 84): 1-41.

5. Corren J. The relationship between allergic rhinitis and bronchial asthma. Curr Opin Pulm Med 1999; 5: $35-7$.

6. Bresciani M, Paradis L, Des Roches A et al. Rhinosinusitis in severe asthma. J Allergy Clin Immunol 2001; 107: 73-80.

7. Dhong H, Kim H, Cho D. Histopathologic characteristics of chronic sinusitis with bronchial asthma. Acta Otolaryngol (Stockholm) 2005; 125: 169-76.

8. Smith T, Mendolia-Loffredo S, Loehrl T et al. Predictive factors and outcomes in endoscopic sinus surgery for chronic rhinosinusitis. Laryngoscope 2005; 115: 2199-205. 
9. Seybt M, NMcMains K, Kountakis S. The prevalence of and effect of asthma on adults with chronic rhinosinusitis. J Ear Nose Throat 2007; 86: 409-11.

10. Awad O, Fasano M, Lee M. Asthma outcomes after endoscopic sinus surgery in aspirhin-tolerant versus aspirhin-induced asthmatic patients. Am J Rhinology 2008; 22: 197-203.

11. Busse W. The relationship between viral infections and asthma. I: Mygind N, Pipkorn U, Dahl R, red. Munksgaard: København, 1990: 123-38.

12. Steinsvåg S, Skadberg B, Bredesen K. Nasal symptoms and signs in children sufferhing from asthma. Int J Pediatr Otorhinolaryngol. 2007; 71 615-21.

13. Denburg J, Keith P. Systemic aspects of chronic rhinosinusitis. Immunol Allergy Clin North Am 2004: 24: 87-102.

14. Rimmer J, Ruhno J. Rhinitis and asthma: united airway disease. Med J Aust 2006; 185: 565-71.

15. Baradin P, Van Herden B, Joubert J. Absence of pulmonary aspiration of sinus content in patients with asthma and sinusitis. J Allergy Clin Immunol 1990; 86: 82-8.

16. Sarhin S, Undem B, Sanico A. The role of the nervous system in rhinitis. J Allergy Clin Immunol 2006; 118: 999-1016

17. Hallani M, Wheatly J, Amis T. Enforced mouth breathing decreases lung function in mild asthmatics. Respirology 2008; 13: 553-8

18. Randolph C. Allergic rhinitis and asthma in the athlete. Allergy Asthma Proc 2006; 27: 104-9.

19. Hens G, Vanaudenaerde B, Bullens D et al. Sinonasal pathology in nonallergic asthma and COPD: United airways disease beyond the scope of allergy. Allergy 2008; 63: 261-7.

20. Melzer E, Teper A, Danzig M. Intranasal corticosteroids in the treatment of acute rhinosinusitis. Curr Allergy Asthma Rep 2008; 8: 133-8.

21. Camargos $P$, Ibiapina $L$, Lasmar $L$ et al. Obtaining concomitant control of allergic rhinitis and asthm with nasally inhaled corticosteroid. Allergy 2007; 62: $310-6$

22. Stelmach R, Nunes $P$, Ribeiro $M$ et al. Effect of treating allergic rhinitis with corticosteroids in patients with mid-to-moderate asthma. Chest 2005; 128: 3140-7.

23. Pedroletti C, Lundahl J, Alving $K$ et al. Effect of nasal steroid treatment on airway inflammation determined by exhaled nitric oxide in allergic schoolchildren with perennial rhinitis and asthma. Pediatr Allergy Immunol 2008; 19: 219-26.

24. Walsh G. Second-generation antihistamines in asthma therapy: is there a protective effect. Am J Respir Med 2002; 1: 27-34.

25. Kim H, Bouchard J, Renzi PM. The link between allergic rhinitis and asthma: a role of antileukotrienes. Can Respir J 2008; 15: 91-8.

26. Møller C, Dreborg S, Ferdousi HA et al. Pollen immunotherapy reduces the development of asthma in children with seasonal rhinoconjunctivitis (The PAT-study). J Allergy Clin Immunol 2002; 109: $251-6$.

27. Vignola A, Humbert M, Bousquet J et al. Efficacy and tolerability of anti immunoglobulin E therapy with omalizumab in patients with concomittant allergic asthma and persistent allergic rhinitis. Allergy 2004; 59: 709-17.

28. Dhong $H$, Jung $Y$, Chung $S$ et al. Effect of endoscopic sinus surgery on asthmatic patients with chronic rhinosinusitis. Otolaryngol Head Neck Surg 2001; 124: 99-104.

29. Saito H, Asakura S, Hata M et al. Does adenotonsillectomy affect the course of bronchial asthma and nasal allergy. Acta Otolaryngol (Stockholm) 1996; (suppl 523): 212-5 